\title{
Health and wellness in III John 2 and its implications for the Yoruba
}

\begin{abstract}
Health and wellness is thing of pride and a priceless possession among the people from the biblical era even to the present dispensation and age. No wonder in III John that the beloved disciple wrote that it is his desire (and God's) that believer should be in health and prosper; while addressing Gaius one of the leaders in the early era of the Church. What does being in health connote in that milieu and in the present among the Yoruba? What is the exact meaning and interpretation of John's statement in his epistle? The aim of this material is to view side by side by comparison whether the statement to be in health and prosper has same meaning in both dispensations among the people concerned. Thus, this research uses both comparative and exegetical methods to arrive at its conclusion. It is observed that both dispensations cherish health and wellness and it is to be pride on than wealth. It is recommended that each individual has a part to play in staying healthy as well as the society which they live in as there is a multi-causal approach to health and wellness.
\end{abstract}

Keywords: health, healing, III John, Yoruba, Nigeria, implication, old testament, new testament
Volume 4 Issue 4 - 2019

\author{
Ruth Oluwakemi Oke \\ Department of Christian Religious Studies, Federal College of \\ Education, Nigeria
}

\begin{abstract}
Correspondence: Ruth Oluwakemi Oke, Department of Christian Religious Studies, Federal College of Education, Nigeria, Tel +2347035262482, +234805 I 26082,
\end{abstract} Email ruthoke0@yahoo.com

Received: July 03, 2019 | Published: August 26, 2019

(estament

\section{Introduction}

Harrison $^{1}$ observes that health and wellness is a thing of pride and a priceless possession among the people of all ages and era. It is a priceless possession which people desired than nothing else, not even riches and wealth. The reason for this is that without good health nothing can be achieved by an individual. Harrison further clarifies that when a man is healthy it is believed that such has physical prowess that is a very versatile condition for the agrarian community which the ancient Israelites were well-known. ${ }^{2}$ My Jewish Learning website reiterates that Jews' close connection to healing, both as patients and physicians, is ancient and rooted in both theology and history. ${ }^{3}$ To Harrison, ${ }^{4}$ the Jews have more understanding and meaning of health than the absence of illness which applied to other communities, including the Yoruba. He reiterates that a state of clinical health is more than absence of illness, but also includes definitive positive considerations. To Harrison a person is healthy when he exhibits a functional state of body and mind with each discharging their duty harmoniously. However, he believes that the Jews priced good health more than any earthly possessions. ${ }^{5}$ The above account for the reason why the Yoruba will say- ilera loro, meaning health is wealth. In fact, Dopamu ${ }^{6}$ emphasises that among the African (and the Yoruba inclusive) to be healthy is to live. What this implied is that when an individual is healthy, it is certain and of optimism that such is wealthy. In direct consonance with this is when one has a retrospect on the huge sum of money that people spent on orthodox medicine, herbal and other natural remedy therapy in other to have good health or stay healthy. The obvious for taking that feat is that they can perform the

${ }^{1}$ RK Harrison. Healing, The interpreter's dictionary of the Bible. In: Buttrick GA, editor. Nashville: Abingdon press; 1962. p. 541-546.

${ }^{2}$ Harrison. Healing. The interpreter's dictionary of the Bible. 1962. p. 541-546.

${ }^{3}$ My Jewish Learning. Jewish Health \& Healing Practices. 2017.

${ }^{4}$ Harrison. $544 \mathrm{p}$.

${ }^{5}$ Harrison. 546 p.

${ }^{6} \mathrm{~A}$ Dopamu. Health and Healing within the Traditional African Religious Context. Orita: Ibadan Journal of Religious Studies. 1985;17(2):66. daily task to acquire wealth, which can never be possible if such is ill or sick.

When a person is ill among the Jews of biblical epoch, he is supposed to look up to the Great Physician who is Yahweh. Harrison $^{7}$ explains that in post- exilic Judaism, looking for healing from physician by the sick is precluded, for they believe that such a procedure will usurp divine prerogative in healing the sick. This idea was also corroborated by my Jewish website ${ }^{8}$ which expresses that in many religions in ancient times, and still in some today, the idea of medical treatment was anathema, even heresy. Disease, accident and deformity were considered no less parts of God's creation than human beings themselves. Medical treatment was considered meddling with God's work and will. This accounts for the reason why the Yoruba will say- ilera loro, meaning health is wealth.

Commenting on healing, Larbi ${ }^{9}$ articulates that in the Bible all sickness is ultimately a result of the fall and disease may be a punishment for violation of God's Law. (Exo. 15:26, Deut. 28:22). $\mathrm{He}$ expresses that continuous obedience to God may ensure good health (Exo. 15:26, Deut. 28:1-14). He however clarifies that in the book of Job, it distinguished that disease does not always represent Divine punishment. He concurs that healing and good health is the manifestation of God's Goodness and Compassion in response to human suffering. He explains that there are two extremes to health and wellness, both of which must be avoided. The first is that godly Christians do not fall sick (Phil. 2:25-30); second is the denial of faith healing (Acts. 28:3-6, ICor.12:9). He confirms that God reserves the prerogative to heal, and that not all diseases in Jesus era were healed; neither all dead were raised to life. There is a prerogative of a duty

${ }^{7}$ Harrison. 546. See also JB Green. Healing. In: T Desmond, Alexander Brian S, Rosner DA, Carson \&Graeme Goldsworthy, editors, New Dictionary of Biblical Theology, Exploring the Unity \& Diversity of Scripture. England \&USA: Inter Varsity Press; 2000. 536 p.

${ }^{8}$ MyJewishLearning. Jewish Health \& Healing Practices. 2017.

${ }^{9}$ Kingsley Larbi. Healing. African Bible Commentary. In: Tokunboh Adeyemo Gen, editor. Michigan: Zondervan. 2006. 447 p. 
to seek God in relationship not only for the benefits, but as a duty to Him.

\section{Idea of health and wellness among the Jews and the Yoruba}

Adamo ${ }^{10}$ notes that there are various words that connote health and healing in the Old Testament ${ }^{11}$ such as shalom, rapha, ared, habash and others. He notes their various interpretations and meanings giving to such words include 'peace', 'prosperity', 'wellness', 'health', 'completeness', 'safety', 'restoration', 'to bind' 'to prolong', all of which have social, spiritual, and economic dimensions. He submits that these words presuppose a state of good health and well- being. Oguntoye $^{12}$ substantiates this view as he believes health should be psychosomatic involving the body and the soul and in harmony with one's community expectation of health. Ogunkunle ${ }^{13}$ subscribes to the views of Adamo and Oguntoye that health is the legitimate concern of the people in the African continent as ill-health is regarded as a misfortune not only in OT and the Bible, but also among the Yoruba This then makes health and wellness an essential ingredient in the life of the people of the Bible epoch and that of the Yoruba.

Vaux ${ }^{14}$ makes inference to the Divine Law specified in the OT as the guiding principle to wellness. He notes that these laws are revealed by divine revelation, publicized to Israelites through the Torah and the prophets. He observes that the Divine Law is both in the realm of moral and natural laws. He articulates there are prophylactic instructions in the OT to safeguard persons from the scourge of illhealth and to live in God's mercy. He mentions some of the premises on which good health is built in the OT which are holiness and purity. Idowu $^{15}$ elucidates that the economy of salvation as explained in the OT is directed towards total well-being which is exemplified by the word- shalom. He implies that salvation is deliverance from a particular adverse or unhappy situation to restoration and or bringing into an auspicious or happy one. This infers that God is the source of health and healing.

Abogunrin ${ }^{16}$ explains that healing is not a new phenomenon in Africa because there are traditional ways of effecting health and wellness. He gives different Greek words connoting healing or a state

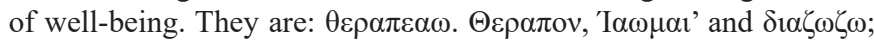
all of which means 'to save', caring for the sick, to cure or to heal' or 'to save thoroughly'. He expresses that healing still subsists in spite of the bias and bigotry exhibited by some scholars due to belief in

${ }^{10} \mathrm{~T}$ Adamo. Healing in the Old Testament and African context. Biblical healing in Africa context. Biblical Studies Series 3. Abogunrin SO, Akao JO, Akintunde DO, Toryough GN, Oguntoye PA, editors. Ibadan: Nigeria Association for Biblical Studies. NABIS; 2004. p. 32-50.

${ }^{11}$ Henceforth OT.

${ }^{12} \mathrm{PA}$ Oguntoye. Healing in the-Testament literature in the Africa context. In: Abogunrin SO, Akao JO, Akintunde DO, Toryough GN, Oguntoye PA, editors. Biblical healing in Africa context. Biblical Studies Series 3. Ibadan: Nigeria Association for Biblical Studies. NABIS; 2004. p. 64-82.

${ }^{13} \mathrm{CO}$ Ogunkunle. Prophet Isaiah and the healing of king in the Yoruba context. In: Abogunrin SO, Akao JO, Akintunde DO, Toryough GN, Oguntoye PA. Biblical healing in Africa context. Biblical Studies Series 3. Ibadan: Nigeria Association for Biblical Studies. NABIS; 2004. p. 51-63.

${ }^{14} \mathrm{~K}$ Vaux. Theological ethics and AIDS: law and Gospel. Current in Theology

and Mission. 1989;16(4):279-281.

${ }^{15}$ EB Idowu. Religion, magic and medicine with special reference to Africa.

Orita: Ibadan Journal of Religious Studies. 1967;1(2);62-74.

${ }^{16} \mathrm{SO}$ Abogunrin. Healing in the African context. Biblical healing in Africa context. Biblical Studies Series 3. Abogunrin SO, Akao JO, Akintunde DO, Toryough GN, Oguntoye PA, editors. Ibadan: Nigeria Association for Biblical Studies 2004. science and the natural law. He further substantiates that healing is still a mainstay of the Christian Apologetics that Church fathers strongly vouched for. Adegoke explains that ${ }^{17}$ modern Western society laid the origin of ill-health within other people such as blaming illness on conflict with spouses, children, family employees or colleagues. But the notion of placing ill-health on others doorsteps are rather common with traditional society. For instance among the Yoruba for one to have sound mind and health, one has to be in consonance with others in one's community apart from the fact of maintain good personal hygiene. However Snow and Johnson ${ }^{18}$ from a research conducted among Black Americans, described illness as a 'reminder' from God for some behavioural lapse, such as neglecting to attend Church worship regularly, prayerlessness or unthankful behaviours! Their opinion is that neither home remedy nor physicians can cure such illnesses, but acknowledging of such individuals shortcoming and seeking God's forgiveness before good health can be attained again. Adegoke ${ }^{19}$ corroborates this and expresses that from a supernatural perspective health is ascribed to supernatural entities such as the gods, devil or ancestral spirit. This is cmmon among the Yoruba.

Adegoke further clarifies that lay theory of illness etiology is multi-causal; ${ }^{20}$ meaning that there are several factors acting together. Factors such as the individual, natural, social and supernatural causes are not mutually exclusive, but are linked together. Morakinyo ${ }^{21}$ cited in Adegoke in a study on Somatic complaints among Yoruba, reported that the ontology of motivation among the Yoruba includes the belief that the wellbeing of a person is also linked with his psychosocial environment through subtle psychological, magical and mystic powers. The implication of this is that for a person to enjoy good health in Yoruba parlance such must be in good standing and favour of all the psycho-social elements and this is equally true of the Israelite as indicated above. In essence, what this connotes is that there are some controlling influences behind the health and wellness of an individual, according to Israelite and Yoruba ethos. In order to achieve this, a typical Yoruba will employ the use of charms, talisman, igbadi(waist band) amulet, asoro, (charms hung on the wall), oruka (ring), ogun (medicine) to facilitate good and sound health. The Yoruba can also go as far as appeasing the dieties, gods or the ancestral spirit associated to their family in order to maintain peace and good health. Likewise, HOIM, ${ }^{22}$ emphasised that a price is attached to good health, even among the Jews of Bible era. It further emphasises the demand for self-control (dietary and other ways) and diligence as some of the price for good health in that epoch. Other according to HOIM is obedience to biblical health laws. ${ }^{23}$

Among the Yoruba ara lile ni oogun oro-Health is wealth and Alafia ni oogun oro. Good health is the magic of wealth. This shows the premium placed on good health by the Yoruba; without good health nobody can make any landmark. Consequently, the Yoruba can go to any length in staying healthy. When people meet in the environment

${ }^{17}$ AA Adegoke. Factors Influencing Health Beliefs among people in South West, Nigeria. African Research Review. 2008;2(1):180.

${ }^{18}$ LF Snow, Johnson SM. Folklore, foof, female reproductive Cycle. Ecology Food and Nutrition. 1978;7:41-49.

${ }^{19}$ AA Adegoke. Factors Influencing Health Beliefs among people in South West Nigeria. African Research Review. 2008;180.

${ }^{20}$ Adegoke. 181.

${ }^{21} \mathrm{O}$ Morakinyo. Phobic States presenting as somatic complaints syndromes in Nigeria, Socio-Cultural factors associated with diagnosis and Psychotherapy. Acta Psychiatari Scadinavian. 1985;71:356-365.

${ }^{22}$ Hope of Israel Ministry. Ancient Bible Health SECRETS Revealed Today! 2017.

${ }^{23}$ Hope of Israel Ministry. Ancient Bible Health SECRETS Revealed Today! 2017. 
the greetings is se alaafia ni (are you in good health?) or se dada ni (I hope all is well). Akintunde ${ }^{24}$ observes that it is people in good health that can fulfil their social, moral as well as spiritual obligations, hence the saying among the Yoruba, Alaafia loju,(Health is paramount) Ilera l'oro, eni to ni alaafia lo lohun gbogbo (health is wealth, the health has everything or is blessed). From the aforementioned it is very evident that the Jews and the Yoruba placed premium on good health and wellness; in fact the Bible specified that if the Israelite obeys His law, they would experience 'none of the diseases' that plagued other nations. (Exo.15:26). HOIM ${ }^{25}$ clarifies that Yahweh gave the laws so that His CHOSEN people could be an example to the world, as $\mathrm{He}$ wants their better health to be noticed by surrounding nations who could then inquire how they could gain the same result (Deut. 4:1-8). After a thorough analysis of the background to health and wellness among both eons, it is expedient to turn a searchlight on the text under study.

\section{Background to III John}

The Gospel of John as well as the three Epistles that had John's name attached to them were believed to be written by John, the Beloved Disciple' who was addressed as John the Elder in the Epistles (II Jn.1,III Jn.1). The consensus about his being addressed as the 'elder', according to Geisler; ${ }^{26}$ is that John at the time of writing the book that bore his name was well stricken in year. It is also a title of seniority and authority. Henry ${ }^{27}$ supports that John is an elder by age and by office and this to Henry, honour and deference are due to both. William Barclay ${ }^{28}$ though differs on the opinion as regards the author, distinguished II and III John as genuine because of their shortness. Barclays ${ }^{29}$ clarifies that these two epistles were so brief and so comparatively unimportant that no one would have gone to the trouble of inventing them into the canon and attaching them to John's name. Falwell ${ }^{30}$ corroborates this by explaining that II and III John have the distinction of being the shortest books of the Bible; as each of the missives has less than three hundred Greek words! He further emphatically reiterates that II and III John cannot be more than the lengthy of a standard papyrus sheet which was 8 by 10 inches. Supporting the authenticity of the Epistle, Falwell cites Church fathers like Eusebius who he claims made reference to these short epistles among the antilegomena (in Ecclessia Historica III.25). To further clarifies the canonicity and genuineness of the II and III epistles Falwell attests that Irenaeus quoted from it twice in his Against Heresies. Clement of Alexander also speaks of John's "longer epistle" which indicated that he must have been aware of these short ones. Stott ${ }^{31}$ points out that the tree epistles are found in the earliest Greek manuscripts and as such there have never been any controversy about their being scripture

\footnotetext{
${ }^{24}$ DO Akintunde. Women as Healers, the Nigeria Yoruba Experience. In: Isabel Phiri, Sarojini Nadar, editors, African Women, religion and Health. Honour of Mercy Amba Ewudziwa Oduyoye. New York: Orbis Books, 2006. 159 p.

${ }^{25}$ Douglas S Winnail. Biblical Health Law. Tomorrow's World. 2004.

${ }^{26}$ Norman L Geisler. III John. A Popular Survey of the New Testament. Michigan: Baker Books; 2007. 301 p.

${ }^{27}$ Matthew Henry. III John. Matthew Henry Commentary of the whole Bible, Complete and Unabridge. USA: Hendriksen; 2003. 2458 p.

${ }^{28}$ Identify the Elder John as another John who must have been an aged person in the Ephesus Church. William Barclays. 1976. The Letters of John and Jude, The Daily Study Bible, Revised Ed., Edinburgh: The Saint Andrews Press, 127.

${ }^{29}$ William Barclays. 1976. $127 \mathrm{p}$.

${ }^{30}$ Jerry Falwell. Ex.ed. Introduction to III John, Liberty Bible Commentary.

Virginia: The Old Time Gospel Hour. 1982. 775 p.

${ }^{31}$ John RW Stott. The Epistles of John. RVG. In: Tasker, editor. Tyndale New

Testament Commentary. Grand Rapids; MI: Eerdmans; 1964. 14f.
}

The issue addressed in III John was about wandering missionaries who were erring from the teaching of the Church, but are capitalizing on the goodwill and hospitality of the Early Church to entertain and house fellow Christian travellers, without measuring to the standard of faith! This was what the elder was warning the Church to be wary about. Falwell ${ }^{32}$ gave insight into the situation of inn in that milieu as being 'flea-infested and rapacious', thereby making the hospitable Church duty-bound to entertain and house itinerant preachers. The III Epistle of John was addressed to Gaius, who was an elder in the Ephesus Church. The epistle's place of provenance was believed to be Ephesus. This was the consensus and orthodox claim of the Church. Credence to the fact above was the history of Apostle John, which was greatly tied to Ephesus; where he lived for a long period of time with the exception of his short banishment to the Isle of Patmos. In fact Falwell, ${ }^{33}$ believed that Apostle John was called to be the Pastor of the Ephesian Church (after receiving the care of Jesus' mother at the crucifixion site (Jn. 19:26-27); where he laboured and served the Church until his death.

\section{The Text, III John 2}

The text from the original language reads: ${ }^{34}$

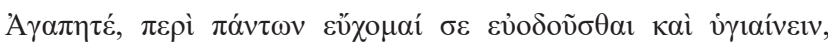

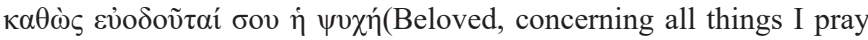
you to prosper and to be in good health, just as prospers your soul).

Falwell's idea on the prayer in verse two is that the prayer is John's wishful prayer for Gaius. In addition, exegeting on verse two, Barclays $^{35}$ expresses that John was acting like his master, Jesus who was always concern about the spiritual as well as physical wellbeing of people. And that both matter for a complete man (sic). Commenting on A A $\alpha \pi \eta \tau \dot{\varepsilon}$-beloved, Barclays pinpoints that the word was used twice in the opening verse of the epistles (v 1a, 2a), and ten times in the group of this epistle (I Jn2:7, 3:2, 4:1, 7, 11, III Jn.1,2, 5, 11). ${ }^{36}$ Alford ${ }^{37}$ says $\tau \omega ́$ $\alpha \gamma \alpha \pi \eta \tau \dot{\varepsilon}$ seems to be used in a general sense in verse1, but here (verse 2), it indicates that Gaius was generally beloved, and the Apostle joins in the affection for him. He further explains that the address began on the note of the beloved in verse 2, than any specific motive, of the supposed ill-health of Gaius. ${ }^{38}$ The phrase, $\pi \varepsilon p i$ $\pi \alpha ́ v \tau \omega \nu$ - meaning concerning, or in respect to all things ; according to Barnes ${ }^{39}$ is an idea that John wished that in all respect Gaius might have the same kind of prosperity which his soul had. The sense of these words is 'in every respect, I wish that it may go as well with you as it does with your soul; that is your worldly prosperity, comfort and your bodily health' John wished Gaius health may be as prosperous as his religion was Barnes' candid idea. Alford's opinion is that $\pi \varepsilon \rho i$ $\pi \alpha ́ v \tau \omega v$ (concerning or above all thing) does not belong together as it was used elsewhere by John himself who used $\pi \varepsilon \rho i$ with other classes of verb, but rather $\pi \varepsilon \rho i$ should be considered with v̛raíveıv(be in health). James, Fausset Brown's ${ }^{40}$ comment is that since Gaius soul is prospering, then his health should also measure up to the prosperity of his spiritual life and this was John's earnest desire for him.

$\Xi$
${ }^{32}$ Falwell. 1982. $775 \mathrm{p}$
${ }^{33}$ Falwell. 775. p.
${ }^{34} \mathrm{http}: / /$ biblehub.com/text/3_john/1-2.htm
${ }^{35}$ Barclays. 148 p.
${ }^{36}$ Barclays. 148. p.
${ }^{37}$ Alford II John 2. Greek Testament Critical Exegetical Commentary. 2017.
${ }^{38}$ Alford II John 2. Greek Testament Critical Exegetical Commentary.
${ }^{39}$ Albert Barnes. III John, Albert Barnes NT Commentary. Power Bible CD.
${ }^{40}$ James- Fausset -Brown. 3 John, James- Fausset -Brown Commentary, Power Bible CD. 
occurs in the New Testament only in Rom. 1:10 and III John, and this literally is rendered to have a prosperous journey. Commenting on

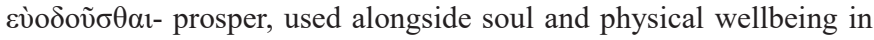
this text. Falwell ${ }^{41}$ aspirates that it literarily means to have a pleasant trip and this came to denote getting along well thus, corroborating Barnes estimation. 1Cor. 16:2, it presages hath prospered; and in the passage before us it means, properly, to lead in a good way; to prosper one's journey; and then to make prosperous; to give success to; to be prospered, which may imply that John wish that everything is going on well with Gaius in good health, physically as well as he is spiritually. Kaì v̛raiveıv and be in health. Ellicott's sommentary for English Readers ${ }^{42}$ exegetes that an Ascetic would be surprised that one of the greatest Apostles is deeply concern about bodily health; but he clarifies that the better a man's health the more thoroughly he can do God's work. He explains that the erring or rebellious at heart can be sick; but a Christian cannot despise the inestimable blessing of sound health. Robertson ${ }^{43}$ comments that in Paul writings, this word always means sound teaching (1Ti 1:10; 6:3), but in this passage and in Luke $5: 31 ; 7: 10 ; 15: 27$, it signifies soundness of bodily health; to enjoy bodily health. It is not necessary to suppose, in order to a correct interpretation of this, that Gaius was at that time suffering from bodily indisposition, though perhaps it is most natural to suppose that, as John makes the wish for his health so prominent. Barnes ${ }^{44}$ supports that it is common, in all circumstances, to wish for the health and prosperity of our friends; and it is as proper as it is common, if we do not give that a degree of prominence above the welfare of the soul. The Preachers Online \& Sermon Bible ${ }^{45}$ exegetes that it seems Gaius apparently is a man who suffered some ill health or disease, or subject to being sickly. But he prospered spiritually, in spite of his illness. The commentary explains further that Gaius ill health is of great concern to John, and he wanted him to know that he is thinking and praying for him to have sound health as well as his soul had soundness.

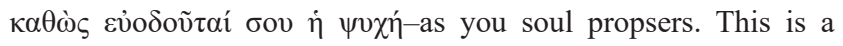
remarkable comparison which assumes the welfare (present middle

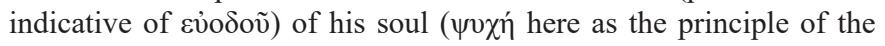

\footnotetext{
${ }^{41}$ Falwell. 778.

${ }^{42}$ Ellicott's Commentary for English Readers. III John 2. 2017.

${ }^{43}$ Robertson's NT Word Picture. III John 2, Robertson's NT Word Pictures; Power Bible CD.

${ }^{44}$ Albert Barnes, Power CD.

${ }^{45}$ NA. 3John. The Preachers' Online \& Sermon Bible Vol 3. I ThessalonianRevelation. India: Authentic Books, 2000. 925 p.
}

higher life as in John 12:27, not of the natural life as in Mt 6:25). ${ }^{46}$ Henry ${ }^{47}$ comments that the prosperity of soul is a greatest blessing in this side of the heaven. He exegetes further that this supposes regeneration and an inner function of spiritual life. His further emphasis that grace and health are two rich companions... he believes that grace will improve health, health will also employ grace. His conclusion is that it is wished that those who have prospered soul may also have healthy bodies too.

\section{Conclusion}

From the exegesis above it is outstanding that health and a wellness are to be priced above any other earthly possession among the Israelite off the era under study and that of the Yoruba. It is to be valued than any earthly possession. For anyone whom to be in health implied must be in tune with Yahweh- in Israelite parlance, or Olorun or Olodumare according to the Yoruba tradition. Of equal importance and value is the ability of the individual to be in sync with their community, thereby observing all health laws and regulations; this is also common to both aeons. The responsibility of personal hygiene and discipline is also not left out in order to stay healthy and have sound healthy, which HOIM $^{48}$ also upheld. To stay in sound body and mind therefore, involves the obedience to statutory health laws as showcased by both the Jews and the Yoruba. It also involves having a reference relationship with Yahweh and Olodumare, God in both traditions. This is imperative as there is a multi-causal approach to health and wellness, as exemplified by both epochs.

\section{Acknowledgments}

None.

\section{Funding}

None.

\section{Conflicts of interest}

Author declares that there is no conflict of interest.

\footnotetext{
${ }^{46}$ Robertson Power CD.

${ }^{47}$ Matthew Henry. III John. Matthew Henry Commentary of the whole Bible. 2003.

${ }^{48}$ Hope of Israel Ministry. Ancient Bible Health SECRETS Revealed Today! 2017.
} 